\title{
Kent Güvenliğinde Cemaatleri/Toplulukları Harekete Geçirmek: Komüniteryanizm ve Toplum Destekli Polislik
}

\author{
Salih Zeki Haklı \\ Polis Akademisi
}

\section{Öz}

1980'li yılların başında Kuzey Amerika'da ortaya çıkan komüniteryan (cemaatçi/toplulukçu) düşünce, liberal bireyciliğe karşı çıkarak; toplumdaki cemaatlerin/toplulukların korunmasını ve geliştirilmesini savunmuştur. Bu manada insanlarm daha sağllklı ve huzurlu şekilde varliklarmı sürdürebilmesi için mensubu oldukları cemaatlerin/toplulukların benimsediği ortak iyi anlayışına uygun bir hayat tarzının sürmelerinin önemine vurgu yapılmaktadır. Komüniteryanizm, kısa süre zarfinda felsefí alanda derin tesirler oluşturduğ u gibi etkisini siyasal ve idarî alanlarda da göstermiştir. Nitekim aynı dönemde ABD ve Ingiltere'de oluşturulan Toplum Destekli Polislik uygulamasında da komüniteryanizmin izleri bulunduğu iddia edilebilir. Son otuz yıllık döneme bakıldığında polisin bu görevleri yerine getirmek için sadece kendi imkanların değil, bu görevle ilgili paydaşları da hizmetin sunumuna dahil etmeye çalıştıkları görülmektedir. Toplum Destekli Polislik anlayışının da bu çerçevede dünyanın birçok ülkesinde geliştirilen yeni bir polislik uygulaması olduğu söylenebilir. Komüniteryanizm insanların içinde yaşadıkları cemaatlerin/topluluklarınn mevcut ve gelecekteki durumları konusunda sorumluluk duymalarmı esas almaktadır. Toplum Destekli Polislik uygulamasl, kent güvenliğini să̆lamak için kentlerdeki cemaatlerden/topluluklardan güvenlik hizmetinin birer parçası olmaların beklemektedir. Böylelikle kentlerdeki asayişin sağlanması daha kolay gerçekleşecek ve toplumun polislik hizmetinden beklentilerinin de karşılanması mümkün olacaktır. Toplum Destekli Polislik bu amaç doğrultusunda hizmet verirken felsefi açıdan komüniteryan düşüncenin temel görüşlerini esas aldığı düşünülmektedir. Bu bakımdan komüniteryan düşüncenin ve Toplum Destekli Polisliğin karşılaştırılmalı olarak incelenmesi halinde karşılıklı etkileşimin ne denli yoğun oldu ̆̆u anlaşılacaktır. Bu çalışmada TDP uygulamasının oluşumunda komüniteryan kavram ve eleştirilerin etkisi incelenecektir. TDP'nin komüniteryanizmin felsefi yaklaşımından beslenmesinin yan sıra liberalizmin komüniteryan eleştirisinin liberal güvenlik anlayışına yönelik eleştirileri nasıl oluşturduğuna temas edilecektir.

Anahtar Kelimeler: Toplum Destekli Polislik, komüniteryanizm, polislik, kent, güvenlik 


\title{
Activating Communities for Urban Security: Communitarianism and Community Policing
}

\author{
Salih Zeki Haklı \\ Turkish National Police Academy
}

\begin{abstract}
Communitarian thought which was emerged at the beginning of the eighties in Northern America has advocated to protect and improve communities in societies by objecting liberal individualism. In this manner, it is emphasized that individuals have to act in accordance with the common good understanding of their communities in order to live more suitable and peaceful. Communitarianism generated deep effects in philosophical studies within the short time as well as in political and governmental areas. Thusly, it is asserted that community policing which was formed in USA and UK has communitarian marks as well. It is seen that the police institutions have tried to carry out these fulfillments not only using their forces but also including relevant stakeholders in service process in the last 30 years. It can be said that community policing is the new policing system that is improved in most countries all over the world. Communitarianism is based on the values that individuals have to feel responsible present and future positions of the people whom they live together. Community Policing expects that communities in cities would become a part of security services. In this way security in cities occurs easily and expectations of society will be happened from policing services. When community policing services through this purpose it also embraces essential principles of communitarian thought in philosophically. It is understood that interaction between communitarian thought and community policing have to be intense in case of analyzing them comparatively from this perspective. It is studied effects of communitarian notions and critics on community policing. It is mentioned how community policing has nourished philosophical approach of communitarianism as well as how it has embraced communitarian critics of liberal security understanding
\end{abstract}

Keywords: Community Policing, communitarianism, policing, city, security 


\section{Giriş}

Bir mekânın kent olarak tanımlanabilmesi için belirli bir hukuki sisteme, idari yapılanmaya, ticarî hayata ve sosyal ilişkiler ağına sahip olması gerektiği kabul edilmektedir. Kente ait bu unsurlardan doğan fonksiyonların sağlıklı şekilde icra edilebilmesi içinse güvenliğin sağlanması tarih boyunca büyük önem arz etmiştir. Nitekim kentlerin yüksek ve kalın surlarla çevrilmesinden özel kuvvetlerce muhafaza edilmesine kadar takip edilen her yöntem bu anlayış çerçevesinde oluşmuştur. Son yüzyıllarda kentlerin yaşadıkları en büyük değişim ve dönüşüm, 18. yüzyılda başlayan sanayileşme süreciyle birlikte ortaya çıkmıştır. Sanayi Devrimi sonrası özellikle Batı Avrupa'daki kentlerin nüfusunda ciddi bir artış görülmesi kentin idarî, hukukî, ticarî ve sosyal ilişkiler ağını değiştirdiği gibi güvenlik anlayışında da birtakım yeni düzenlemeleri beraberinde getirmiştir.

Sanayileşme sonrası daha fazla sayıda işgücüne ihtiyaç duyan büyük fabrikalar, kırlardan kentlere doğru olan göç hareketlerini hızlandırmıştır. Nitekim bu dönemle birlikte yeni sanayi kentleri kurulduğu gibi, mevcut kentlerin nüfusunda ciddi bir artışın ortaya çıktığ1 görülmüştür. 20. yüzyılın başında Londra, Paris ve Berlin'in nüfusu bir önceki yüzyılın başına göre altı kattan fazla bir artış göstermiştir (Roberts, 2011, s. 705). Kentlerde nüfusun bu denli hızlı artması ve de yeni kentlerin kurulması kentlerin güvenliğini sağlamada yeni yöntemlerin kullanılmasını zaruri kılmıştır. Nitekim bu döneme kadar askerî birlikler tarafından sağlanan kent güvenliğine ilişkin hizmetler, görevleri sadece kentlerdeki asayiş sorunlarıla ilgilenmek olan ve de bu amaçla kurulan yeni polis teşkilatlarının sorumluluğuna devredilmiştir (Heywood, 2015, s. 491).

Bu açıdan bakıldığında Batı Avrupa'da ve sonrasında dünyanın farklı yerlerinde, polis teşkilatlarının kurulmaları ile kentleşme arasında doğru orantı olduğu görülmektedir. Nitekim 17. ila 19. yüzyıllar arasında Batı Avrupa'daki kentler büyük bir hizla gelişirken, 17. yüzyılda Fransa'da, 18. yüzyılda Almanya'da ve 19. Yüzyılda İngiltere'de ve İtalya'da polis teşkilatları kurulmaya başlamıştır. Kentlerdeki asayiş sorununu çözmek için kurulan polis teşkilatları, kentlerde yaşanan siyasal ve sosyal gelişmelere bağlı olarak, ilerleyen dönemler içerisinde yeni suçlarla da mücadele etmek durumunda kalmıştır. Özellikle Sanayi Devrimi sonrasında siyasal ve toplumsal hayatta sosyalist ve anarşist düşüncelerin etkin olmaya başlaması ve bu fikirlerin siyasal düzene ve de kent yaşamına yönelik şiddet eylemlerinde bulunması kentin toplumsal dokusunu etkilediği gibi, polislik faaliyetine 
de yeni görevlerin eklenmesine sebebiyet vermiştir. Özellikle 19. yüzyılda anarşist ve devrimci terör saldırıları sonrası devletler hem rejimlerini hem de vatandaşlarının can ve mal güvenliğini koruyacak bir tedbir olarak polislik faaliyetine daha büyük önem vermişlerdir. Bu gelişmeler neticesinde, kentlerdeki güvenlik sorunlarının arasına özellikle terör olaylarının da eklenmesiyle, kentlerde hizmet veren polis teşkilatlarının sorumluluk alanı genişleme göstermeye devam etmiştir (Martin, 2017, s. 55).

Görüldüğü üzere, polis tarihi açısından bakıldığında, polis teşkilatının ortaya çıkışında kentleşmenin büyük etkisi olduğu gibi polisliğin gelişmesinde kentte yaşanan siyasal, ekonomik ve sosyal gelişim ve değişimlerin de derin etkileri olmuştur. Günümüzde dünyanın birçok ülkesindeki emniyet teşkilatları kentlerdeki güvenliği daha sağlam hale getirmek için farklı yöntemler takip etmektedirler. Kentleşmenin getirdiği yeni düzen, polis teşkilatlarının yapısında ve hizmetlerinde bir dizi yeniliği beraberinde getirmektedir. Kentin siyasal, ekonomik ve toplumsal yapısındaki değişimler klasik yöntemleri işlevsiz hale getirmekte ve polislik faaliyetinin yeni yöntemlere ihtiyaç duymasına yol açmaktadır. Bu kapsamda son otuz yıllık dönemde polislik faaliyetleri açısından tecrübe edilen en önemli yöntemlerin başında Toplum Destekli Polislik (TDP) uygulaması gelmektedir.

Özellikle 1960'lardan itibaren kentlerde savaş karşıtı ve çevreci hareketler başta olmak üzere "yeni toplumsal hareketlerin" ortaya çıkması sonucunda siyasal rejimler, bu hareketlerin taleplerini dikkate alan politikalar benimseme yolunu seçmişlerdir. Ayrıca, kamusal hizmetlerin sunumunda hizmet alıcıların memnuniyetini artırmak kamu yönetiminin temel hedefleri arasında yer almaya başlamıştır. Toplumsal hayattaki ve kamu yönetiminde yaşanan bu gelişmeler, kent güvenliğinin sağlanmasında da toplumun beklentilerinin esas alınması düşüncesini ön plana çıkarmıştır. Polis sayısının artırılması veya motorize ve yaya devriyelerinin çoğaltılması gibi klasik yöntemlerin kent güvenliğini ve toplum memnuniyetini sağlamak açısından istenen düzeyde başarı yakalayamaması, kentte yaşayan insanların da güvenlik sürecine dahil edilmeleri gerektiği düşüncesini ortaya ç1karmıştır. Böylelikle, 1980'li yılların başında, kent güvenliğine ilişkin hizmetlerin sunumunda idarenin ve toplumun iş birliğini hedefleyen TDP uygulaması devreye sokulmuştur.

Güvenliğe yönelik bu yeni demokratik ve katılımcı bakış açısından hareketle, TDP'yi toplum ve polis arasındaki iş birliğini geliştiren yeni bir polislik stratejisi olarak değerlendiren yaklaşımlar bulunmaktadır (Donnely, 2006, s. 15.). TDP'yi bir polislik stratejisi olarak gören bu yaklaşımın aksine, 
TDP'nin temelinde güçlü bir felsefi altyapının bulunduğunu iddia eden görüşler de yer almaktadır (Wisler ve Onwudiwe, 2009, s. 5.). Bu felsefe TDP anlayışının çerçevesini belirlemenin yanı sıra, böyle bir anlayışa duyulan ihtiyacı siyasî ve toplumsal manada meşrulaştıran bir yapıya da sahip olduğuna işaret etmektedir. Güvenliği temin etmek için polis ile belirli bir bölgede yaşayan insanların birlikte hareket etmelerini öngören TDP, elbette, güvenlik gibi kamusal hizmetlerin daha demokratik ve katılımcı bir çerçevede gerçekleştirilmesini hedefleyen yeni bir polislik stratejisi olarak değerlendirilebilir. Bununla birlikte TDP'nin, bu demokratik idealin yanı sıra, insanların mukim oldukları bölgelerde birlikte yaşadıkları insanların yaşamlarına ve geleceklerine olan duyarlılıklarını artırmayı esas alan 'komüniteryanizm (cemaatçilik/toplulukçuluk)' düşüncesinden felsefî anlamda beslendiği görülebilir. Bu makalenin temel iddiasını da, 1980'li yıllarda etkisini ilk olarak akademik sonra da siyasi alanda ciddi manada göstermiş olan komüniteryanizm düşüncesinin kent güvenliğini sağlamak konusunda TDP'nin felsefî açıdan doğmasına ve gelişmesine büyük katkılar sağladığı oluşturmaktadır.

\section{Kent Güvenliğini Sağlamada Toplum Destekli Polisliğin Önemi}

Günümüzde polis güçlerinin temel görevleri; suçu önlemek ve tespit etmek, kamu düzenini sağlamak ve yardıma ihtiyacı olanlara destek olmak şeklinde sıralanmaktadır (Osse, 2008, s. 81). Görüleceği üzere polislik faaliyetinin temel görevi olan güvenliği sağlamanın yanı sıra, polisten farklı kamusal hizmetleri de yerine getirmesi beklenmektedir. Son otuz yıllık dönemde polisin bu görevleri yerine getirmek için sadece kendi imkanlarını değil, bu görevle ilgili paydaşları da hizmetin sunumuna dahil etmeye çalıştıkları görülmektedir. TDP anlayışının da bu çerçevede dünyanın birçok ülkesinde geliştirilen yeni bir polislik uygulaması olduğu söylenebilir.

Elbette polislik faaliyeti olarak tatbik edilen yöntemler büyük ölçüde devlet yönetimine hâkim olan siyasî ve idarî anlayışa bağlı olmaktadır. Zira polis, devletin otoritesinin toplumsal hayata yansiyan görüntülerinin başında yer almaktadır. Bu bakımdan polislik faaliyeti, yaklaşık üç yüz yıllık tarihi boyunca, devlet yönetiminde yaşanan değişimlerin etkisini hissetmiş ve kendi kurumsal yapısında da benzer bir dönüşüm sürecini yaşamıştır. Elbette bu süre zarfinda siyasal hayattaki dönüşüm neticesinde hizmet tanımında da farklılıklar ortaya çıkmıştır. Nitekim devletlerin, özellikle 2. 
Dünya Savaşı'ndan sonra, vatandaşlarının maddi ve manevi gelişimlerinden kendilerini daha fazla sorumlu tutmaya başlamaları sonucu polisliğin de toplumsal hayattaki görüntüsünde değişiklikler yaşanmaya başlanmıştır. Bu bakımdan günümüzde polisin başlıca vazifeleri arasında suçu önlemek ve tespit etmenin yanı sıra, kişilerin temel hak ve özgürlüklerinin korunmasının, halkın asayişinin sağlanmasının, halka yönelik sosyal yardım ve hizmet süreçlerine katılmasının sayılması bu sorumluluk alanının ne denli geliştiğini açıkça göstermektedir (Avrupa Güvenlik ve İşbirliği Teşkilat1, 2016, s. 15).

Son yıllarda kentlerin güvenliğini ve huzurunu temin etmek için, özellikle ABD ve Batı Avrupa'da, tercih edilen modern bir polislik anlayışı olan TDP'nin uygulanmaya başlanmasında bu yeni siyasal gelişmelerin etkisi olduğu görülmektedir. Polisin, tıpkı diğer kamu kurumları gibi, daha demokratik ve şeffaf bir sistem dahilinde çalışmasını öngören TDP, polis ve toplum arasındaki iletişimin kuvvetlenmesini ve sürekli olmasını hedeflemektedir. Elbette iletişimin diğer tarafı olan toplumun da bu süreçte etkin bir yapıda olması önem taşımaktadır. 1980'li yılların başında geliştirilmeye başlanan TDP, böyle bir etkileşimi sağlama amacıyla kurgulanmıştır. Bu süreçte kent sakinlerinden içinde yaşadıkları toplumun asayiş sorunundan toplumun genel yaşam kalitesine kadar birçok meselede interaktif bir iletişim sürecinin parçası olması beklenmektedir. Oluşturulacak topluluk danışma kurulları, polis-toplum atölyeleri, halka açık toplantılar veya polis merkezlerinde kurulan halkla temas noktaları gibi merkezler aracılı̆̆ıla polislik faaliyetinin kalitesi artırılmak istenmektedir. Elbette bu hedefe ulaşılabilmesi için polisin gayretlerinin yanı sıra, kent sakinlerinin de maddi ve manevi güvenliği tesis etme hususlarında sorumlu birer aktöre dönüşmeleri arzu edilmektedir (AGİT, 2016, s. 48).

TDP'nin ortaya çıkışında klasik polislik uygulamalarının istenen ölçüde başarılı olmadığı düşüncesi de yatmaktadır. Polis sayısının artırılması, devriye araçların ve yaya polislerin daha sık kontrole çıkması gibi klasik yöntemlerin suçu önleme konusunda çok da fazla caydırıcı olmadığı genel kabul görmektedir. Bu sorunlardan hareketle, son y1llarda polislik anlay1şında, daha çok gönüllüğü teşvik eden ve hizmet alıcıya en az masrafla en iyi hizmeti sunmaya çalışan TDP uygulamasının tercih edildiğine şahit olunmaktadır (Gleizal, 2000, s. 340). Bu bakımdan, TDP uygulamasının devreye sokulmasıyla birlikte, polisin başarısı sadece suçun önlenmesi veya aydınlatılması üzerinden değerlendirilmemektedir. Bu temel görevlerinin yanı sıra polisin esas etkisi, toplumla geliştirdiği ilişkilerin seviyesi ve de 
suçla mücadelede toplumun katılımını sağlamadaki başarısı çerçevesinde dikkate alınmaktadır. Bu sebeple toplumun polise güveni ve desteği sağlanmadan polisin vazifelerini tam olarak yapamayacağ 1 yeni polislik anlayışının temel ilkeleri arasında yer almaktadır (Aydın, 2006, s. 145.). Dünyanın birçok ülkesindeki polis teşkilatlarının TDP uygulamalarına ağırlık vermelerinin temelinde de bu yeni anlayış yatmaktadır.

TDP uygulamasinda toplumdan beklenen temel husus, polisin görevini yerine getirirken izleyeceği yol, yöntem ve taktikleri belirlemede daima polisin yanında yer almasıdır. Bu yakınlaşmanın sağlanabilmesi için polis kadar toplumu oluşturan bireylerden de bazı fedakârlıklarda bulunması beklenmektedir (Aydın, 2006, s. 145). Bu beklentinin kapsamını, kısaca, belirli bir bölgede (şehir/mahalle/sokak) yaşayan insanların polislikle ilgili karar verme süreçlerine katılmaları ve de ikamet ettikleri bölgede yaşanan veya yaşanması muhtemel güvenlik sorunları karşısında daha aktif bir rol üstlenmeleri teşkil etmektedir.

TDP kapsamında gerçekleştirilmek istenen temel hedef, esasında, insanların gösterdikleri fedakârlık karşısında kentteki toplumsal dokunun daha güçlü hale gelmesini sağlamaktır. Bu nedenle, TDP toplumun sosyal yapisına dişarıdan dayatılan bir ödev olmaktan ziyade, toplum tarafından özümsenmesi gereken ve de her daim toplumsal iş birliğini esas alan bir polislik yaklaşımı olarak görülmektedir (Clements, 2008, s.125). Bu özümseme ve iş birliğinin insanların birlikte yaşadıkları komşularının hayatlarına karşı daha duyarlı olmalarını ve onların güvenlik sorunlarını kendi sorunları olarak kabul etmelerini sağlaması beklenmektedir. Bu temel hedef doğrultusunda TDP, kendi yaşadıkları bölgeyi kontrol edebilen ve ayrıca kendilerine yetebilen topluluklar meydana getirmeyi amaçlamaktadır. Halka kendi sorunlarını çözmede yardımcı olmak, yerel kuruluşları geliştirmek ve sosyal sorunları suç haline gelmeden proaktif bir çalışma yaparak çözmek bu kapsamda değerlendirilmektedir (Adams, Rohe, Arcury, 2005, s.44-45).

TDP, bu temel önceliklerden hareketle, belirli bölgelerdeki suç ve uyuşturucu gibi asayiş sorunlarını çözme konularında olduğu kadar; suç korkusu, komşuluk ilişkilerindeki zayıflama, sosyal ve fiziksel rahatsızlıklar gibi toplumsal sorunları tanımlamak ve çözmek için de polis ve toplumun birlikte çalışmaları gerektiği düşüncesine dayanmaktadır. Böylelikle insanların hayatlarını sürdürdüğü bölgedeki toplam yaşam kalitesini de artırmayı amaçlamaktadır (Donnely, 2006, s.15). 


\section{Kentlileri Bir Arada Tutmak: Komüniteryanizm}

TDP'nin oluşmasında ve gelişiminde komüniteryanizm düşüncenin oldukça büyük etkisinin olduğu söylenebilir. 1970'li yıllarda John Rawls, Robert Nozick ve Ronald Dworkin gibi düşünürlerin yazdıkları eserler sonucunda yeniden etkili hale gelen liberal bireycilik fikri, önce entelektüel ortamda sonrasında ise siyasette etkin bir konuma yükselmiştir. Bu gelişmelerin sonucunda, 1980'li yılların başında liberal bireyciliğe yönelik Michael Sandel, Alasdair MacIntyre, Charles Taylor ve Amitai Etzioni gibi düşünürlerin yazdıkları başta olmak üzere birtakım komüniteryan eleştiriler getirilmeye başlanmıştır. Tercih hürriyetinin ve serbestçe belirlenen hayat tarzının korunmasına dayanan liberal bireyciliği yanlış ve zararlı gören bu yeni cemaatçi/toplulukçu anlayış, insanların içinde yaşadıkları cemaatler/topluluklar sayesinde belirli bir zihnî ve hissî yeterliliğe ulaştıklarını ileri sürmüşlerdir. Komüniteryanizm düşüncesi, insanların daha iyi bir toplumsal düzen içinde yaşayabilmeleri için mensubu oldukları cemaatlerin/toplukların benimsediği ortak iyi anlayışını kabul etmeleri ve bu iyi anlayış doğrultusunda hayat tarzlarını belirlemeleri gerektiğini savunmuştur (Haklı, 2017, s.16).

Komüniteryan düşünürlere göre cemaatlerin/toplulukların, insanların rastgele oluşturdukları toplumsal yapılar olarak görülmeleri kabul edilemez. Böyle tesadüfi yaklaşımların ötesinde bu yapıların, geçmişten gelen ve geçen süre zarfında güçlenen bir gelenekten beslenen ortak bir yaşam biçimini temsil ettikleri belirtilmektedir (Buchanan, 1989, s.857). Sosyolojik olarak bakıldığında her insanın bir cemaat/topluluk olarak değerlendirilebilecek birer aile içinde doğup büyüdüğü görülmektedir. Bununla birlikte insanların kendi hayatlarını sürdürebilecek yeterliliğe sadece aileleri sayesinde ulaşabilmeleri mümkün değildir. Bunun için kişinin eşleri, çocukları, dostları ve diğer insanlarla ilişki kurması gerekmekte olup, bunu yapabilmesi sayesinde gerçek birer yetişkin olarak büyüyebileceklerdir. İnsanlar, kendi kimliklerini de bu sosyal ilişkiler üzerine kurulu olan belirli bir kültür dairesi sayesinde oluşturabilmektedirler (Taylor, 1990, s.204-205).

Komüniteryan düşünürler, bir cemaatin/topluluğun benimseyeceği 'iyi anlayışı' ile insanların gerçekleştirecekleri doğru eylem arasında oldukça önemli bir bağın bulunduğunu kabul etmektedirler. Liberal bireyciliğin, insanın üzerindeki bir dünyaya atıfta bulunan bu düşünce sistemini yok saymasının, insanın kendi iyiliğinin başka insanların iyiliğine bağlı olduğu hakikatinin unutulmasına sebebiyet verdiğini ifade etmektedirler. Buradan hareketle komüniteryanlar için iyi yaşamı mümkün kılan en önemli sosyal 
yapılardan biri olan cemaatin/topluluğun iki temel unsuru bulunmaktadır: Araçsal olarak nitelendirilebilecek birinci unsura göre, cemaatin/topluluğun her bir üyesi diğer kişilerin amaçlarına ulaşmasına yardımcı olmak zorundadır. Bu özelliği itibariyle cemaat/topluluk bir anlamda şahsî çıkarların gerçekleşmesini sağlayan bir araç hüviyetine bürünmektedir. Kurucu olarak nitelendirilebilecek ikinci unsura göre ise Aristoteles' in "insan doğası gereği sosyal bir hayvandır" sözünden hareketle bu cümlede geçen "doğası gereği" ifadesinin sadece başlangıçtaki bir durumu değil, aynı zamanda nihaî bir noktaya karşılık geldiğini düşünmektedirler. Zira insanın başka bir insanın bütün kişiliğini geliştirebilmesi, ancak değişmez bir şekilde tanzim edilmiş bir düzen içinde yaşayan diğer insanların yardımı sayesinde mümkün olabilecektir (Gewirth, 1996, s.15).

Komüniteryan düşünürlere göre, insan herhangi bir eylemde bulunurken veya bir şeyi yapmaktan vazgeçerken bir arada yaşadığı diğer insanları da dikkate alması halinde ahlâkî bir varlık olarak değerlendirilebilir. Örneğin Zygmunt Bauman, Habil ve Kabil hikâyesindeki ahlâksızlığın başladığı anı Kabil'in Habil'i öldürmesinden ziyade, kardeşinin nerede olduğunu soran Tanriya Kabil'in öfkeyle, "Ben kardeşimin bekçisi miyim?" demesi olarak görmektedir. Oysaki Bauman'a göre, herkes kardeşinin bekçisidir, çünkü kardeşinin iyiliği kişinin ne yaptığına ya da neyi yapmadığına kaçınılmaz olarak bağlı bulunmaktadır (Bauman, 2011, s.93). Komüniteryan düşünce, Bauman'ın anlattığı bu hikâyeden hareketle, cemaate/topluluğa mensup herkesin bir arada yaşadığı başka kişilerin hayatlarını ve geleceğini önemsemesi gerektiğini ileri sürmektedir.

Önemli komüniteryan düşünürlerden birisi olan Charles Taylor da bir cemaate/topluluğa mensup kişilerin, ortak değerlerin ne denli büyük öneme sahip olduğunu görmelerinin önemli bir sosyal karşılığının olduğunu ifade etmektedir. Taylor'a göre, insanların kendi güvenliklerini sağlayabilmek adına, örneğin, Montréal şehir topluluğuna dahil olmaları bariz şekilde bir şahsî çıkar üzerine kurulabilir. Buna karşın insanların belirli bir cemaate/topluluğa ait "ortak iyiliği" tesis etmek için verdikleri ahlâkî bütün sözler esasında diğerkâmlığa dayanmaktadır. Taylor bu noktada bir cumhuriyete bağlı vatandaşlar arasındaki dayanışma duygusunun başlı başına bir kıymet taşıyan "kader ortaklığını" esas aldığını belirtmektedir. Bu kader ortaklığının, cemaate/topluluğa mensup kişilerin başka kişilere ve cemaate/topluluğa sağlam şekilde bağlanmasını sağlayan erdem ve vatanseverliği koruduğunu ve geliştirdiğini ifade etmektedir. İşte tam da bu noktada 
ortak bir amaç etrafında toplanmış kişilerin yaşanan sıkıntılara birlikte göğüs germelerinin cemaatin/topluluğun nasil bir işleve sahip olduğunu gösterdiğini de eklemektedir (Taylor, 2006, s.89).

\section{TDP'nin Doğuşunda ve Gelişmesinde Komüniteryanizmin Etkisi}

Liberalizmin komüniteryan eleştirisi, özellikle Anglo-Sakson dünyada, kısa sürede büyük bir ilgiye mazhar olmuştur. Bu ilgi sadece akademik düzeyde kalmamış siyasi ve idari alanlarda da etkisini göstermiştir. Nitekim 1990'11 yıllarda Amerika Birleşik Devletleri Başkanı Bill Clinton'ın ve İngiltere Başbakanı Tony Blair'in söylemlerine ve uyguladıkları politikalara bakıld1ğında komüniteryan düşünceden büyük ölçüde esinlendikleri görülmektedir (Frazer, 1999, s.12,13, 36 ve 37; Galston, 1993, s.219). Buradan hareketle, kentlerdeki güvenlik sorununu daha hızlı ve etkili şekilde çözmek amacıyla tesis edilen TDP uygulamasının, kent güvenliği sürecine kentlerde yaşamakta olan cemaatleri/toplulukları birincil aktör olarak dahil etmeyi amaçlamaları da komüniteryan düşüncenin siyasal ve idarî alandaki bir diğer tesiri şeklinde değerlendirilebilir.

Kent güvenliğini sağlamak konusunda komüniteryanizmin TDP uygulamasını desteklemesinde ve felsefî manada beslemesinde, siyasal ve toplumsal açıdan eleştirdiği, liberalizmin benimsemiş olduğu güvenlik anlay1şının da etkisi olduğu görülebilir. Komüniteryan düşüncenin, liberal siyaset ve toplum anlayışına yönelik eleştirilerinden hareketle, liberal güvenlik anlayışını da kabul edilemez bulacağını düşünmek mümkündür. Liberal siyaset ve toplum anlayışının temelinde, esasında, bireyin güvenliğini sağlamanın yattığ görülmektedir. Birçok liberalin siyaset ve güvenlik anlayışının başlangıç noktasını oluşturan kurgusal "Sosyal Sözleşme Teorileri" de güvenliği sağlama sorumluluğunun bireyden siyasî iktidara devredilmesinin hikâyesini de içermektedir.

John Locke'un ve Thomas Hobbes'un dile getirdikleri sosyal sözleşme teorilerine göre, bireyler siyasî iktidarın olmadığ doğa durumunda sınırsız özgürlüklere sahip olsalar da aralarındaki güvenlik sorunlarını adilane şekilde çözmekten mahrumdurlar. Böyle bir durumda güçlü olanın daha güçsüz olana dilediği şekilde davranma tehlikesinin ortaya çıkması kaçınılmazdır. Bireyler bu istenmeyen durumu önlemek ve de kendi güvenliklerini tesis edebilmek için doğuştan sahip oldukları doğal haklarının bir kısmından feragat etmek suretiyle devlet denen kurumu oluşturmaya rıza göstermişlerdir. Böylelikle bireyler güvenliği sağlama görevini, zor kullanma gücünü 
meşru olarak kullanacak yegâne kurum olan, devlete devretmişlerdir (Arnhart, 2004, s.249). Nitekim liberal güvenlik anlayışı da bu bireyler ile devlet arasındaki bu sözleşme üzerinden kurgulanmış olup; belirli bir siyasî ve toplumsal düzende güvenlikle ilgili düzenlemelerin ve uygulamaların sadece devletle ve özelde de güvenlik güçleriyle sınırlı olduğu kabul edilmiştir.

Sosyal sözleşme teorilerindeki bu anlayış bireye kendi veya birlikte yaşadığı diğer insanların güvenlikleriyle ilgili herhangi bir yasal ve idarî sorumluluk yüklememektedir. Ayrıca liberalizme göre iç güvenliği tesis eden polislik, siyasal ve toplumsal hayat açısından, gerekli bir güç olmakla birlikte bireylerin haklarını ve özgürlüklerini koruyarak kamu düzenini muhafaza etmekten başka bir göreve sahip bulunmamaktadır. Bu yaklaşıma göre polis, bireyi ve onun hak ve özgürlüklerini koruyan ve ayrıca iç düzeni sağlayan tarafsız ve sınırlı bir idarî kuruma karşılık gelmektedir. Polis ilkesel olarak vatandaşları birbirinden koruma göreviyle donatıldığı için, liberal güvenlik anlayışı açısından, polislik faaliyetinin de hukukun üstünlüğünü korumaktan daha geniş bir anlamı bulunmamaktadır (Heywood, 2015, s.492).

Liberal güvenlik yaklaşımının yukarıda zikredilen görüşlerinin komüniteryan düşünce ve TDP uygulaması tarafından kabul edilebilmeleri pek mümkün görünmemektedir. Bu nedenle, komüniteryan düşünce ve TDP uygulamasının birbirlerinden oldukça fazla esinlendikleri ve dahası birbirlerini felsefî açıdan besledikleri ve destekledikleri ileri sürülebilir. Öyle ki bu iddiayı kanıtlayacak birtakım açık deliller bulunmaktadır. Komüniteryanizm ve TDP arasındaki güçlü bağı gösteren hususların başında komüniteryanizm ve de TDP'nin hemen hemen aynı dönemde -1980'lerin ilk yıllarında- Amerika Birleşik Devletleri, Kanada ve İngiltere'de ortaya çıkmaları gelmektedir. Ayrıca her iki kavramın etimolojik olarak cemaat/topluluk kelimesinden türetilmiş oldukları görülmektedir. Toplum Destekli Polis kavramı, İngilizce 'Community Policing' ve Fransizca 'La Police Communautaire' kelimeleriyle ifade edilirken; komüniteryanizm kavramının İngilizce karşılığı ise 'Communitarianism' kelimesidir. Her iki öğenin ayn dönemde ve bölgede ortaya çıkması ile aynı kelime köküne sahip bulunmaları kadar, temel özne olarak cemaati/topluluğu esas almaları bir diğer önemli benzerliği oluşturmaktadır. Nitekim kent hayatındaki insanın varlığını ve kimliğini mensubu olduğu cemaatler aracılığıyla korumaya çalışan komüniteryanizm, kent güvenliğinin gündemini de kendi prensipleri ekseninde 
etkilemeyi başarmış görünmektedir. Böylelikle komüniteryan düşünce cemaatlerin/toplulukların korunması ve geliştirilmesini savunurken; TDP ise bu cemaatlerin/toplulukların toplumsal hayat kadar kamusal alanda da faal olmasinı talep etmektedir.

Komüniteryan düşünce ve TDP arasında böyle bir kavramsal ve ilkesel benzerlik olduğu gibi, karşılaştıkları tehditler açısından da benzerliklerin bulunduğu dile getirilebilir. Özellikle günümüzdeki modern kentler, sahip oldukları temel özellikler itibariyle gerek komüniteryan değerler sistemi gerekse güvenliğin sağlanması açısından birtakım olumsuz durumların ortaya çıkmasına sebebiyet verebilmektedir. Kentlerin farklı inanç ve düşüncede kişilerin birlikte yaşadıkları heterojen bir toplumsal yapıya sahip yerleşim birimleri olduğu, bu yerlerde sosyal hareketliliğin oldukça yoğun şekilde yaşandığı ve kentlerdeki ilişkiler ağının kişisel olmayan ilişkilere dayandığ1 görülmektedir (Gökulu, 2010, s.213).

TDP anlayışının polislik uygulaması olarak benimsenmesinin altında yatan nedenler ile komüniteryanizmin yukarıda zikredilen toplumsal endişeleri arasında da büyük benzerliklerin olduğu anlaşılmaktadır. 1980'li yıllardan önce ABD'de ve Batı Avrupa'da polisin toplumla kurduğu sosyal ilişkideki eksikliklerin ve zayıf iletişimin, toplum ile polis arasında anlaşmazlıklara ve yabanclaşmaya neden olduğu belirtilmiştir. Bu sorun insanların temel hak ve özgürlükler konusunda büyük bir bilince sahip bulunmalarına bağlı olarak polise yönelik şikayetlerin artmasıyla sonuçlanmıştır (Donnely, 2006, s.18.). Kentlerin bu yeni özellikleri, komüniteryan düşüncenin endişe ettiği anominin ve toplumsal kargaşanın ortaya çımasına yol açabileceği gibi, polisin kentlerdeki güvenliği sağlamaya çalışması esnasında kent sakinlerinden beklediği destek ve yardımı almasını da zorlaştırmaktadır. Bu sebeple TDP'nin kentlerde daha aktif şekilde uygulamaya çalışılmasıyla birlikte anomi ve toplumsal kargaşanın oluşması önlenmeye çalışılmakta ve aynı zamanda cemaatleri/toplulukları güvenlik konusunda harekete geçirecek ahlâkî motivasyon da meydana getirilmek istenmektedir. Belirli konularda uyum içerisinde olan bir toplumsal yapının oluşturulmasl; artan sosyal hareketliliğin hem toplum hem de güvenlik birimlerince daha kontrol edilebilir hale gelmesi ve güvenliğin konusuna dahil edilebilecek ilişkiler ağının yeniden kişiler arası seviyeye çekilmesine gayret edildiği görülmektedir. Modern kentleri cemaatten cemiyete geçiş mekanları olarak tasvir eden Georg Simmel'in tanımlamasından hareket edecek olursak, komüniteryan düşüncenin bu geçişi tersine çevirmeye çalışmak sure- 
tiyle kentin içinde cemiyetten cemaate doğru yeniden bir dönüşümü sağlamayı amaçladığı anlaşılmaktadır. TDP uygulaması da bu toplumsal fırsattan yararlanarak yeni kentli cemaatin güvenliğini interaktif bir etkileşim süreci çerçevesinde gerçekleştirmeyi hedeflemektedir. TDP'nin varlık şartlarının başında yer alan suçun gerçekleşmeden önlenmesine öncelik verilmesi, polis teşkilatlarının toplumla iş birliği imkanlarını geliştirecek şekilde teşkilat yapılarını yeniden tasarlamaları ve de halkın katılımını etkin şekilde sağlamak ilkeleri (Osse, 2008, s.96), kentlerdeki bu komüniteryan dönüşüm üzerine inşa edilmektedir.

Komüniteryanizm modern dönemde şehirlerde mukim insanların temel değerlere olan ilgisinin azaldığından ve insanların birbirleriyle olan temasının seyrelmiş olmasından şikâyet etmektedir. Bu olumsuz durumu ortadan kaldırmak içinse toplumun yeniden komünal temel değerlere bağlı şekilde bir araya gelmesini ve de insanların birbirlerine karşı sorumluluk taşıyacak şekilde hayatlarını tasarlamalarını hedeflemektedir. Bu noktada, TDP ile komüniteryanizm arasındaki ilişki cemaatlerin/toplulukların idari bir işleme etkin şekilde nasıl katılacağı meselesi etrafında şekillenmektedir. Zira, belirli değerler ve sorumluluk anlayışı ekseninde bir araya gelen yerel toplulukların komüniteryan düşünce tarafından korunmasından ve geliştirilmesinden en çok istifade eden uygulamaların başında TDP gelmektedir. TDP, yerel toplulukların problemlerini ve önceliklerini tespit ederek gerekli çözümleri sağlamaya çalışmasının yanı sıra kentin farklı bölgelerindeki güvenliği sağlamak konusunda bu bilinçli cemaatlerin/toplulukların yard1mına ihtiyaç duymaktadır. Bu yardım neticesinde TDP, belirli bir bölgede yaşayan insanlarla iş birliği yapmak suretiyle adem-i merkeziyetçiliği ve insanların yönetime daha çok katıldıkları bir anlayışı meydana getirmektedir (Kalunta-Crumption, 2009, s.153). Böylelikle TDP uygulaması, polis teşkilatlarının güçlerinin ve otoritelerinin bir kısmını terk etmelerini esas alarak, insanların içinde yaşadıkları cemaatle/toplulukla birlikte güvenliği ve adaleti tesis etmeleri için belirli bir toplumsal katılımı sağlamaktadır (Wright, 2001, s.158).

Burada komüniteryanizmin küçük cemaatleri önemseyen ve onu her türlü tehlikeden korumaya çalışan yaklaşımının izleri açıkça görülmektedir. Zira komüniteryan düşünce liberal bireycilik kadar bürokratik yoğunlaşmanın da cemaatleri/toplulukları tehdit ettiğine inanmaktadır. Önemli komüniteryan düşünürlerden Alasdair MacIntyre, ideal cemaatlerin/toplulukların bireycilik kadar aşırı devletçiliğin olumsuz tesirlerinden korunması gerekti- 
ğini ifade etmektedir (MacIntyre, 2001, s.62). Bu nedenle TDP'nin cemaatleri/toplulukları merkeze alan bu ademi merkeziyetçi ve katılımcı yaklaşımının komüniteryan hassasiyetlerle uyumlu olduğu görülmektedir.

Heterojen kentlerdeki cemaatlerin/toplulukların korunmalarını ve gelişmelerini sağlamak sağlıklı bir toplumsal yapının tesisi kadar suçun önlenmesi açısından da firsatlar sunmaktadır. Kentlerdeki suça yol açan nedenleri izah eden bilimsel çalışmalarda aile değerlerinin kaybolması ve kent sakinlerinin suça kayıtsızlıkları sıklıkla dile getirilmektedir. Bu tespitler komüniteryan düşünürler ile güvenlik güçlerinin ortak sorunlarla mücadele ettiğini gösterir niteliktedir. Çocukların kimliğinin ve kişiliğinin gelişmesinde önemli işleve sahip olduğu kabul edilen ailedeki duygusal bağların zayıflaması ailenin suçu engelleyecek eğitimi vermesini engellediği düşünülmektedir. Aynı şekilde kentlerde yaşayan kişilerin suçla ilgili kanunlardan, yasal haklarından ve ceza adalet sisteminden habersiz olmalarının yanı sıra birlikte yaşadıkları insanların hayatlarına karşı kayıtsız kalmalarının da suçu artıran bir özelliğe sahip olduğu kabul edilmektedir (Leones, 2006, s.133-150). Bu iki kaygının komüniteryan eleştirinin içeriğiyle aynı olduğu görülmektedir. Komüniteryanizm, bu tehlikelerden hareketle, ailevi ilişkilerin korunmasını, toplumdaki herkesin kendisini büyük bir ailenin mensubu gibi görmesini ve böylelikle insanların birbirlerine olan kayıtsızlıklarına son vermesini amaçlamaktadır. Komüniteryan düşünürler, cemaat/topluluk hayatının en çok ihtiyaç duyduğu güvenliğin cemaat/topluluk bağlarının yeniden kurulması sayesinde polis veya okula başvurulmaksızın dahi sağlanabileceğini düşünmektedirler. Bu ideal durumun gerçekleşmesi içinse cemaate/topluluğa bağlı herkesin bir başka kişinin can ve mal güvenliğini sağlanmasına yardımcı olması gerekmektedir (Etzioni, 1993b, s.139).

TDP anlayışı da bu komüniteryan hedeften destek almak suretiyle kentleri daha güvenli yaşam alanları halinde getirmeyi ve bu yöntem neticesinde kentteki yaşam kalitesini artırmayı hedeflemektedir. Özellikle toplumdaki herkesin mukim olduğu bölgeye ve bir arada yaşadığı diğer kişilere karşı sorumluluğuna vurgu yapılmaktadır. Bu nedenle, komüniteryan düşünürlerden Amitai Etzioni de TDP'yi komüniteryan unsurlardan birisi olarak değerlendirmektedir (Etzioni, 1993a, s.46-47). Etzioni, toplumda yer alan bütün kurumların cemaatleri/toplulukları korumayı ve geliştirmeyi daha çok dikkate alması ve faaliyetleri açısından komüniteryan amaçları da benimsemesi halinde, TDP gibi uygulamaların daha etkin çalışacağını ve de daha fazla ilgiye mazhar olacağına inanmaktadır (Etzioni, 1993b, s.139). 
Komüniteryanlar, liberal bireyciliğin aksine, iyi toplumun kişilerin tercihleri veya rızaları doğrultusunda değil, ortak yaşam düşüncesi sayesinde meydana geleceğini ileri sürmektedirler. Ortak yaşam düşüncesi, insanların sadece temel ihtiyaçlarını karşılamak için oluşturdukları toplumsal yapıdan çok daha fazlasına karşılık gelmekte ve her bir kişinin bir arada yaşadığı diğer kişilere sürekli yardımda bulunmasına dayanmaktadır. Nitekim Etzioni, bu hususla ilgili olarak Birmingham'daki cemaat/topluluk üyelerinin suçları önlemek için oluşturdukları ve TDP uygulamasının bir unsurunu oluşturan "Komşuluk Gözetim Topluluğu” adındaki mahalle birliğini örnek göstermektedir. Bu birliğin takımlar halinde mahallede gezerek suç oranını azaltmış olmasının, bireysel çıarlar üzerinden değil, tam aksine ortak yaşamın sağlamış olduğu sosyal fayda ve dayanışma gibi komünal ilkeler üzerinden anlaşılabileceğini dile getirmektedir (Etzioni, 2000, s.19).

Polis destekli mahalle gözetleme timleri TDP'nin en bariz komüniteryan unsuru olarak görülebilir. ABD, İngiltere ve Japonya' da en yaygın TDP uygulamalarının başında "komşuluk gözetim" (neighborhood watch) sistemi yer almaktadır. Bu sistem gayrı resmi bir toplumsal denetim mekanizmasına karşılık gelmektedir. Özellikle mahallelerin o bölgede mukim insanlar tarafından korunmasının işlenen suç sayısında her zaman bir azalmayı sağlamasa da güvensizlik duygusunu büyük ölçüde azalttığı kabul edilmektedir (Gleizal, 2000, s.344). TDP uygulaması, suçu önleme konusunda yerel toplulukların kendi bölgelerinde gayrı resmi şekilde suça yönelik yaptıkları bu tür sosyal kontrollerin o bölgedeki suçları önlemede önemli bir yere sahip olduğunu benimsemektedir. Bu yorum yerel topluluktaki tüm kesimlerin sürece dahil olması ve etkin katılım göstermesi gerektiğini de kabul etmektedir (Kalunta-Crumption, 2009, s.157). TDP'nin yerel topluluklardan beklentileri ile Etzioni'nin savunduğu ve övdüğü değerler ile uygulamaların birbirine ne denli yakın olduğu açıkça görülmektedir.

\section{Sonuç}

Komüniteryanizm ve TDP'nin ortaya çıkışlarında ve gelişimlerinde kente olan bakışta yaşanan değişimin büyük etkisi olduğu görülmektedir. Bu bakımdan kentte yaşayan insanların hangi sosyal değerler çerçevesinde hayatlarını sürdürecekleri ile hangi güvenlik anlayışı ekseninde kendilerinin korunacağı meseleleri kaçınılmaz olarak kente yüklenen anlamla doğru orantılı şekilde gerçekleşmektedir. Nitekim klasik kent sosyolojisi teorileri, kentleri piyasa ekonomisine ve bürokratikleşmeye dayalı mekanlar olarak 
tasvir etmektedir. Böyle bir kent yapısının ise, modern dönemde, sosyal değerlerle bağlı yerel cemaatleri/toplulukları küresel olanın tehdidiyle karşı karşıya bıraktığından ve de her türlü sosyal yapı ve anlam üretme biçimine adeta düşmanca davrandığından yakınılmaktadırlar (Smith, 2001, s.103).

Komüniteryan düşüncenin ve TDP'nin bu endişeden hareketle kentlerdeki cemaatleri/toplulukları bir arada tutmayı ve onları kent hayatının bütün safhalarına katmayı amaçlamaktadır. Bu bağlamda TDP'nin komüniteryan düşünceden büyük ölçüde esinlendiği ve onun temel ilkeleri çerçevesinde yeni bir polislik anlayışı kurmaya çalıştı̆̆ı anlaşılmaktadır. Bu makalede komüniteryanizm ile TDP arasındaki kuvvetli ilişkinin mahiyeti tarihî ve felsefî açıdan izah edilmektedir. Sonuç kısmında ise her iki anlayış arasındaki değer ve ilkeler arasında büyük benzerlikler olduğu gibi her iki sisteme yönelik eleştirilerin de benzerlik taşıdığı hususu üzerinde durulacaktır.

TDP'nin doğduğu ve geliştiği ABD ve Batı Avrupa'da bu yeni uygulamaya dönük getirilen eleştirilerin başında günümüzde cemaat olgusunun parçalanıyor olduğu endişesi gelmektedir. İnsanların birbirleriyle kısmi zaman dilimlerinde karşılaşıyor olmalarının zayıf ilişkiler ağını beraberinde getirdiği belirtilmektedir. Bu sebeple polise ihtiyaç duyulan bölgelerdeki polislik faaliyeti, toplum ile o bölgede yaşayanların tanıdıkları ve belirli bir uyum içinde oldukları polisler arasında olmaktan ziyade bu zayıf ilişkiler ağının üzerine kurulmaktadır. Ayrıca samimi insani ilişkilerin kurulduğu belirtilen kamusal alanların güvenliğini sağlamada yaşanan başarısızlıklar da başka türlü sosyal parçalanmışlıklara yol açabilmektedir. Özellikle birçok insan açısından kamusal alanlardaki suç korkusunun grafitilerden, k1rık pencerelerden, zarar verilmiş mülklerden ve köşe başlarındaki gençlerden daha fazla olduğu belirtilmektedir (Wright, 2001, s.164).

Cemaatlerin/toplulukların farklı farklı yapılarda teşekkül etmeleri ve her cemaatin/topluluğun polisle iş birliği yapmak konusunda aynı arzuyu taşımamaları bir diğer eleştiri konusunu teşkil etmektedir (Clements, 2008, s. 128). Günümüzde şehirler birbirinden farklı düşünceye, inanca ve hayat tarzına sahip kişilerin yaşadığı yerleşim yerleri haline gelmiş durumdadır. Özellikle şehirler arasında ve şehrin içinde mobilizasyonun sürekli ve oldukça hızlı şekilde gerçekleştiği de bilinmektedir. Böyle bir kentleşme çerçevesinde insanları ortak değerler etrafında bir araya getirmek ve birbirlerine karşı sorumluluk duygusuyla yaklaşmalarını sağlamak pek de kolay görünmemektedir. Ayrıca insanların aynı mahalleyi veya bölgeyi paylaşmalarına rağmen birbirlerini gözetlemelerini ve birbirleri üzerinde sosyal 
bir denetim mekanizması kurmalarını sağlamak da pek kolay görünmemektedir. İnsanların hukukî ve yasal olarak sahip oldukları hakları ileri sürerek bu gözetleme ve denetleme sürecini gayrı meşru ve yasadışı olarak nitelemeleri pekâlâ mümkündür.

Bilhassa "mahalle gözetim" uygulamasının hayattan beklentisinin çok az olduğu kişilerin yaşadıkları bölgelerde büyük engellerle karşı karşıya olduğu belirtilmektedir. Bu uygulamaya yönelik pasif tutumun orta sınıfın oluşturduğu topluluklarda yaşandığı bilinmekle birlikte, esasında bu durumun suç oranın yüksek olduğu, heterojen ve geçici nüfusun yaşadığı ve de topluluk bağının oldukça zayıf olduğu şehir merkezlerinde yaşandığı görülmektedir. Ayrıca sosyo-ekonomik açıdan oldukça fazla sorun bulunan, yüksek oranda suç işlenen ve de polisle olan güven ilişkisinde problemler olan topluluklar, TDP'ye oldukça fazla ihtiyaç duymalarına karşın polisin kendi hayatlarına müdahil olmasından rahatsızlık duyduğu belirtilmektedir (Kalunta-Crumption, 2009, s.158).

Belirli bir bölgede yaşayan insanların komşuların güvenliğini sağlamak için yapacakları gözetleme görevinin içerdiği tehlikeleri komüniteryan düşünürler fark etmektedirler. Nitekim Etzioni gözetlemenin mahiyeti ve s1nırları konusunda uyarı yapma gereği duymaktadır. Zira gözetleme görevi en nihayetinde başkalarının hayatlarını gözetlemeyi içermektedir. Fakat bu görevin farklı sosyal ve ırkî gruplara mensup kişileri dışlamak için veya başka insanların kişisel ilişkilerine müdahil olmak için kullanılmaması gerektiğini 1srarla vurgulamaktadır (Etzioni, 1993, s.140). 


\title{
Extended Abstract
}

\section{Activating Communities for Urban Security: Communitarianism and Community Policing}

*

\author{
Salih Zeki Haklı \\ Turkish National Police Academy
}

Urbanization effected policing progress through its political, economic and social evolution and alteration as well as its appearance in modern history. In this context, the most favored method in policing has been community policing for thirty years especially in USA and UK. It is asserted that community policing which includes democratic and participatory values is a policing strategy which ensured corporation between police and society. On the contrary, it is also stated that community policing has a strong philosophical substructure rather than strategical elements.

Community policing request some essential actions from communities in the cities that they cooperate with the polices when they decide methods of struggle against crimes. It is expected that individuals should make some sacrifices for ensuring this cooperation as well as polices. The expectations are constituted that people living in a certain district (cities/neighborhoods/streets) should participate decision making progresses in policing and should act more actively against crime actions in their district.

Community policing involves an interaction among people living in a certain community. So, it is evaluated as a policing strategy that aims to present public services with more democratic and participatory means. However, community policing gets support from communitarianism which is based on common good concept and solidarity among people as well as from democratic ideals. It is claimed in this article that communitarianism that impress both intellectual and political studies has a profound influence on emerging and improving of community policing in 1980's.

Notion of liberal individualism that became more effective again in 1970's through John Rawls, Robert Nozick and Ronald Dworkin's works 
has a great position in intellectual field as well as in politics. Having notion of liberal individualism gained more importance from intellectuals and politicians within the short time, communitarian scholars such as Michael Sandel, Alasdair MacIntyre, Charles Taylor and Amitai Etzioni started to criticize it intensively. Communitarian thought advocates that people will be able to live a better political and social order if they embrace common good concept of their communities and change their life styles by taking into consideration general life style of them.

It is seen that there are too many common principles and concerns between community policing and communitarian thought. Thusly, weak communication and lack of strong social relations between police and citizens about urban security caused conflicts and alienation in modern societies before 1980's in USA and Western Europe. This problem was resulted in arising complaint about policing services that conscious of the people thrived on rights and liberties. New dimensions of modern cities caused anomy and social disorders in characteristic of societal relationships that communitarian thought worried to happen these huge social problems. Besides, it also leads that police can't enough support and assistance from people while it tries to ensure urban security in the cities.

It is prevented to emerge anomy and social disorders by implementing community policing more actively in the cities. Moral motivations also are asked to emerge in order to mobilized local communities about urban security at the same time. In this context, it is aimed that members of societies embrace common goods and values of communities peacefully and that rising social mobilities can be controlled by both police and people and that relation networks on urban security make happen again among people finally. So, to prevent crimes before happening and redesigning policing services in accordance with improving cooperation between police and people and ensuring principle of active participation of people constructed on communitarian transformation in modern cities. To prevent and to flourish communities in heterogenous cities makes possible emerging healthy societal relationships as well as suppressing crimes in modern cities.

It is stated repeatedly in criminological studies that the crimes happen because of disappearing of family values and negligence about crime actions in modern cities. Since moral education which has an important function on improving identity and character of children in families is the most effective element against crimes, emotional ties among members of the family had to be protected by using communitarian values. It is mostly 
accepted that crime rates in modern cities increase constantly due to fact that people living in modern cities don't have any information about laws on crimes, legal rights and justice system of their country.

As it can be seen community policing and communitarian thought share too many values and concepts. In addition, neighborhood watch system the most apparent communitarian element of community policing. It is the most prevalent community policing application that implements in USA, UK and Japan. It resembles as an informal social control mechanism in neighborhoods. This system doesn't always guarantee to decrease rate of crimes in modern cities but it is accepted that the system decreases sense of insecurity among members of the community. Community policing services embrace that local communities can ensure to prevent possible crime actions in their districts by controlling extra-ordinary situations regularly. This interpretation also accepts that all various parts of local communities get involved actively in the security system. Expectations of community policing from local communities and the values that are advocated and praised by communitarian thinkers are so closed each other.

\section{Kaynakça/References}

Adams, R. E., Rohe, W. M., Arcury, T. A. (2005). Awareness of community-oriented policing and neighborhood perceptions in five small to midsize cities, Journal of Criminal Justice 33 (2005) ss.43-54 aktaran Palacı, M. (2008). Toplum destekli polislik uygulaması. (Yayınlanmamış doktora tezi). Gebze Yüksek Teknoloji Enstitüsü Sosyal Bilimler Enstitüsü, Gebze.

AGIT. (2016). Demokratik polislik kılavuzu. (D. Orhun, Çev.). Ankara: Polis Akademisi Yayınları.

Arnhart, L. (2004). Siyasi düşünce tarihi. (A. K. Bayram, Çev.). Ankara: Adres Yayınları. Aydın, A. H. (2006). Kamu yönetimi ve polis. Ankara: Gazi Kitabevi.

Bauman, Z. (2011). Bireyselleşmiş toplum. (Y. Alogan, Çev.). İstanbul: Ayrıntı Yayınları. Buchanan, A. (1989). Assessing the communitarian critique of liberalism. Ethics, 99(4), ss.852-.882.

Clements, P. (2008). Policing a diverse society. New York: Oxford University Press.

Donnely, D. (2006). Community policing. Kurian, G. T. (Ed.), World encylopedia of police forces and correctional systems içinde (ss.15-22). USA: Thomson Gale.

Etzioni, A. (1993a, 15 Mart). Clinton and the spirit of community. Legal Times. ss. 4647.

Etzioni, A. (1993b). The sprit of community. New York: Crown Publishers.

Etzioni, A. (2000). The third way to good society. London: Demos Panton House.

Frazer, E. (1999). The problems of communitarian politics unity and conflict. New York: Oxford University Press. 
Galston, W. (1993). The promise of communitarianism. National Civic Review, 82(3). ss.217-220.

Gewirth, A. (1996). The community of rights. Chicago: The University Of Chicago Press.

Gleizal, J.-J. (2000). Batı demokrasilerinde polis. (M. Kandemir, Çev.). Ankara: Temiz Yayınları.

Gökulu, G. (2010). Kent güvenliği kentleşme ve suç ilişkisi. Atatürk Üniversitesi İktisadi ve İdari Bilimler Dergisi, 24/1, ss.209-226.

Haklı, S. Z. (2017). Özgür toplumda birey ve cemaat. Ankara: Liberte Yayınları.

Heywood, A. (2015). Siyaset. (B.B. Özipek vd., Çev.). Ankara: Adres Yayınları.

Kalunta-Crumption, A. (2009). Patterns of community policing in britain. Wisler, D. and Onwudiwe I. D. (Eds.). Community policing international patterns and comparative perspectives içinde (ss.149-166). Florida: CRC Press.

Leones, S.V.C. (2006). The current situation of crime associated with urbanization: problems experienced and countermeasures initiated in the philippines. United Nations Asia and Far East Instutue for the Prevention of Crime and the Treatment of Offenders (UNAFEİ). 68. ss. 133-150 aktaran Gökulu, G. (2010). Kent güvenliği kentleşme ve suç ilişkisi. Atatürk Üniversitesi İktisadi ve İdari Bilimler Dergisi, 24/1, ss. 209226.

MacIntyre, A. (2001). Erdem peşinde ahlak teorisi üzerine bir çalışma. (M. Özcan, Çev.). İstanbul: Ayrıntı Yayınları.

Martin, G. (2017). Terörizm kavramlar ve kuramlar. (İ. Çapçıŏlu, B. Metin, Çev.). Ankara: Adres Yayınları.

Osse, A. (2008). Polislik faaliyetini anlamak. Amsterdam: Uluslararası Af Örgütü.

Roberts, J.M. (2011). Dünya tarihi 18. yüzyıl ve sonrası c.2. (İ. Erman, T. Akgün, Çev.). İstanbul: İnkılap Yayınları.

Smith, M. P. (2001). Transnational urbanism locating globalization. Malden: Blackwell Publishing.

Taylor, C. (1990). Philosophy and human scince. Cambridge: Cambridge University Press.

Taylor, C. (2006). Yanlış anlaşmalar: cemaatçi-liberal tartışması. (A. Berten v.d. Eds.). Liberaller ve cemaatçiler içinde (B. Demir v.d., Çev.). Ankara: Dost Kitabevi.

Wisler, D. and Onwudiwe, I. D. (2009). Rethinking police and society community policing in comparision. Wisler D. and Onwudiwe I. D. (Eds.). Commnity policing international patterns and comparative perspectives içinde (ss.1-17). Florida: CRC Press.

Wright, A. (2001) Policing a diverse of cultures: community policing in transformin societies. Kadar, A. (Ed.). Police in transition içinde (ss.157-175). Hungary: Central European University Press.

Salih Zeki Haklı, 1982 yılında Ankara' da doğdu. İlk ve orta öğretimini bu şehirde tamamladı. 2004 yılında Gazi Üniversitesi İktisadi ve İdari Bilimler Fakültesi Kamu Yönetimi Bölümünden mezun oldu. Yüksek Lisans ve Doktora öğretimini Gazi Üniversitesi Sosyal Bilimler 
Enstitüsü Siyaset ve Sosyal Bilimler Bölümünde tamamladı. 2005-2016 yılları arasında Türkiye Odalar ve Borsalar Birliği'nde çalıştı. 2016 yılının Şubat ayından itibaren ise Polis Akademisi Güvenlik Bilimleri Enstitüsü'nde öğretim üyesi olarak görev yapmaktadır. Evli ve iki çocuk babasıdır.

Salih Zeki Haklı, He was born in Ankara in 1982. He studied secondary and high schools in this city. In 2004, he graduated at Gazi University Public Administration Department. He completed his master degree and $\mathrm{PhD}$ at Gazi University Institute of Politics and Social Sciences. He had worked in Union of the Chambers and the Commodity Exchanges of Turkey between 2005 and 2016. He has been still working at Turkish National Police Academy since 2016. He is married and has two children.

E-mail: szhakli@gmail.com

\section{Kaynakça Bilgisi / Citation Information}

Haklı, S.Z. (2018). Kent güvenliğinde cemaatleri/toplulukları harekete geçirmek: Komüniteryanizm ve toplum destekli polislik. IDEALKENT - Kent Araştırmaları Dergisi, 23, 8-29. 